\title{
Sediment mixed layer as a proxy for benthic ecosystem process and function
}

\author{
L. R. Teal ${ }^{1,3, *}$, E. R. Parker ${ }^{2}$, M. Solan ${ }^{1}$ \\ ${ }^{1}$ Oceanlab, University of Aberdeen, Main Street, Newburgh, Aberdeenshire AB41 6AA, UK \\ ${ }^{2}$ Centre for Fisheries and Aquaculture Science (CEFAS), Pakefield Road, Lowestoft, Suffolk NR33 0HT, UK
}

${ }^{3}$ Present address: Institute for Marine Resource and Ecosystem Studies (IMARES), Haringkade 1, Ijmuiden, The Netherlands

\begin{abstract}
Faunal mediated particle and porewater mixing (bioturbation) alters the structure of the surface sediment layer, forming a distinct mixed layer, where the majority of organic matter degradation takes place. Current methods of assessing benthic habitat quality often reference this mixed layer as an indicator of benthic activity. Whilst a great deal of effort has been devoted to linking macro-invertebrate activity to the mixing depth, less attention has been given to defining what the mixing depth represents in terms of ecosystem process and function. Here, in situ sediment profile images are analysed using grey scale intensity analysis to distinguish the mixed zone and relate it to the physicochemical environment in order to determine the biological, chemical and physical variables most influential in its formation. Significant differences were found between biogeochemical conditions within the mixed layer relative to the underlying historic sediment layer. These were attributed to a combination of environmental variables ( $\mathrm{Fe}, \mathrm{Mn}, \mathrm{Si}$, chlorophyll a and $\mathrm{NO}_{3}{ }^{-}$) rather than a single dominant driver of change. Although these findings are consistent across multiple locations, the driver(s) that influence the depth of the mixed layer are site- and season-specific. The mixing depth thus provides a reasonable approximation of benthic ecosystem functioning, but when considering ecosystem process the link between the mixing depth and its driving factors (faunal mixing, food input, environmental conditions) is highly context-dependent. Conclusions on benthic community dynamics and ecosystem process, including assessments of habitat quality, cannot therefore be drawn from estimates of the mixing depth alone.
\end{abstract}

KEY WORDS: Sediment mixing depth - Sediment profile imaging $\cdot$ Sediment colour $\cdot$ Benthic habitat quality $\cdot$ Bioturbation

\section{INTRODUCTION}

One of the key biohistoric events of the last billion years was the so-called 'Cambrian substrate revolution', which describes the diversification of animal burrowing during the early Cambrian period (Seilacher \& Pflüger 1994). Prior to this period, surface layers of marine sediments were characterised by low water content and a sediment-water interface covered by microbial mats (Gehling 1999). The advent of vertically oriented burrow systems (McIlroy \& Logan 1999) disrupted these microbial matgrounds (Seilacher \& Pflüger 1994) and increased sediment water content as the surface layers became increasingly homogenised by faunal mediated particle and porewater fluid mixing (Bottjer et al. 2000). The distinct bioturbated zone, commonly referred to as the 'mixed layer' or 'mixing depth', is where the majority of organic matter degradation takes place (Witte et al. 2003), driven largely by the bacterial population and the availability of electron acceptors (Aller 1982). The development of the sediment mixing depth, and the consequent increase in nutrient and electron acceptor supply to microbes, positively affected levels of ocean productivity and the diversification of marine life (Martin et al. 2008). Understanding the importance of present day spatiotemporal variations in the mixing depth and the extent to which these are driven by infauna is there- 
fore essential if we are to fully understand the contributions that benthic communities make to global biogeochemical cycles.

A recent review estimates the mean mixing depth of the present day global ocean seafloor to be $5.75 \pm$ $5.67 \mathrm{~cm}$, equivalent to an estimated global volume of mixed sediment of $\geq 20700 \mathrm{~km}^{3}$ (Teal et al. 2008). The mixing depth, however, is highly variable at local (Carpenter et al. 1985), regional (Nilsson \& Rosenberg 1997, Diaz 2004) and global scales (Teal et al. 2008), reflecting processes that operate at various spatial and temporal scales and the consequent mosaics of benthic community structure (Johnson 1972, Zajac 2001). Although it is widely accepted that biological communities influence the depth of the mixed layer (Pearson \& Rosenberg 1978), it has been argued that the mixing depth can primarily reflect physical disturbance (e.g. in intertidal/estuarine areas, Dellapenna et al. 1998; in deep areas, Yingst \& Aller 1982, Diaz 2004) and environmental factors (e.g. oxygen depletion, Nilsson \& Rosenberg 1997; organic enrichment, Pearson \& Rosenberg 1978, Valente et al. 1992), including the supply and availability of food, rather than the activity of benthic infauna per se (Boudreau 1998, Smith \& Rabouille 2002). Whilst the relative contributions of these factors to the mixing depth have yet to be fully defined, the link between the extent of the mixing layer, major ecosystem processes and benthic biodiversity is usually tacitly accepted.

The sediment mixing depth is thus routinely used as a convenient proxy for benthic function (e.g. Solan et al. 2004) and habitat quality (Rhoads \& Germano 1986, Valente et al. 1992, Nilsson \& Rosenberg 1997, Rosenberg et al. 2004). Nevertheless, descriptions of the mixing depth remain vague (e.g. 'the depth over which biological mixing occurs', Guinasso \& Shink 1975, p. 3033; 'an indicator of bioturbation', Solan et al. 2004, p. 1178), vary across scientific disciplines and tend to be dependent upon the objectives of the study (Teal et al. 2008). Differences in terminology and usage seem to be largely a function of methodology (e.g. modelling tracer profiles versus interpreting sediment profile images) rather than being based on explicit examinations of what is actually being measured (Rosenberg et al. 2001, Diaz \& Trefry 2006, Teal et al. 2009). Furthermore, a clear definition of what delimits the upper and lower boundaries of the mixing zone is lacking: should the mixing depth encompass only the depth of the surface layer where the infauna is most abundant (i.e. where the distribution of tracers is homogenised, e.g. Dellapenna et al. 1998), or the maximum depth of mixing (= maximum tracer penetration, e.g. Smith \& Rabouille 2002) to ensure that conveyor processing and/or extended deep galleries (e.g. by Callianassa spp., Suchanek 1983) are incorporated into the estimate?
Problems with definitions and terminology are further complicated owing to the inconsistency of methods used to determine mixing depth. Tracer-derived mixing depths, for instance, are tracer-dependent, as they vary with the timescale over which the tracer is integrating mixing events (Lecroart et al. 2007, Teal et al. 2008) and reflect the potential for particle selectivity (Wheatcroft 1992, Smith et al. 1993). Interpretations of the mixing depth from images are also problematic. Reflective (light coloured) sediment is assumed to delineate oxic layers of sediment; however, oxidised ferric iron, which gives sediment the red-brown colour (Fenchel 1969, Lyle 1983, Bull \& Williamson 2001), can persist long after associated porewater has been depleted of dissolved oxygen (Revsbech et al. 1979). Colour is therefore more likely to be linked to iron redox conditions and oxidising environments rather than availability of free oxygen (Teal et al. 2009). Yet few studies have attempted to directly explain, or link, the colour (or a measure of image brightness/intensity) of the sediment profile with measures of oxygen or redox. Where attempts have been made (Rosenberg et al. 2001, Diaz \& Trefry 2006), low sample numbers have meant that interpretation of image derived mixing depths is limited and somewhat vague. The link between sediment colour, sediment redox conditions and infaunal activity nevertheless remains intuitive and has been demonstrated qualitatively (e.g. Rhoads \& Germano 1986).

Recent marine policy (e.g. Marine Bill, UK; Water Framework Directive, EU; Clean Water Act, USA) has emphasised the need to protect specific habitats or species. Although widely accepted, the necessary tools for evaluating benthic habitat quality (e.g. Rosenberg et al. 2004) are based on phenomenological paradigms of ecological succession and a qualitative understanding of how organism-sediment relations alter the status of the habitat (for review, see Diaz et al. 2004). Current methods of assessing and summarising habitat quality routinely reference macro-invertebrate activity (bioturbation) and/or directly assess the mixing depth. The relative importance of these components for habitat quality, however, relies on limited experimentation or correlative field sampling (Snelgrove \& Butman 1994).

Given the importance, tractability and convenience of the mixing depth as a means of evaluating habitat quality, influencing management decisions and informing future conservation strategy, this in situ study was performed to (1) investigate what the image derived mixing depth represents in terms of sediment chemistry and physical properties and, thus, whether higher reflective sediment differs distinctly from lower reflectance sediment in terms of its contribution to benthic function, and (2) determine which biological and environmental parameters influence the depth of 
the step-change in grey scale intensity in the sediment profile. Results of the study are discussed in relation to the validity of using the image derived mixing depth as a proxy for benthic process and function, with particular reference to assessments of biogeochemical cycling and benthic habitat quality.

\section{MATERIALS AND METHODS}

Sample collection and study sites. The interpretation of mixing depths determined from vertical changes in the sediment profile requires information on what such changes represent in terms of sediment geochemistry (objective 1) as well as an understanding of what biological and physicochemical factors influence any step-change in the apparent structure of the sediment profile (objective 2). For objective 1, 7 stations (6 stations and the Oyster Gound central station) were sampled at random within a $500 \mathrm{~m}$ bullring at the Oyster Ground $\left(54.41^{\circ} \mathrm{N}, 4.04^{\circ} \mathrm{E}\right)$ in the North Sea (Fig. 1) during February 2007, and a full suite of sediment parameters was measured alongside sediment colour. For objective 2, it was necessary to obtain some variability in mixing depths as well as in the biological and environmental parameters potentially influencing it. Therefore, sampling was carried out during 5 separate months (February, April, May, September and October) and at 2 sites, the Oyster Ground (central station) and the North Dogger $\left(55.68^{\circ} \mathrm{N}, 2.28^{\circ} \mathrm{E}\right.$, Fig. 1). The temporal samples ensured that the full seasonal variability associated with the winter, and with preand post-spring and autumn bloom periods, was captured and the 2 stations allowed for an examination of the consistency of results between 2 different regions.

For all sampling stations and each sampling month, sediment cores were collected using a NIOZ corer $(\varnothing=$ $30 \mathrm{~cm}$ ). Macrofauna were identified from the returns of 4 intact NIOZ cores (sieved on a $1 \mathrm{~mm}$ mesh) taken from within a $50 \mathrm{~m}$ radius around the station. Fauna were stored in a $4 \%$ formaldehyde/seawater solution and, with the exception of the polychaetes (family), were identified to species level. Total biomass (blotted wet weight) per species and sample was determined in the laboratory. Fragments of organisms were identified and weighed at family level, but no counts were made.

Replicate subsample cores $(\varnothing=5.5 \mathrm{~cm})$ were taken from further consecutive NIOZ cores to avoid pseudoreplication and analysed for sediment particle size $(\mathrm{n}=4)$, porosity $(\mathrm{n}=3)$, organic carbon $(\mathrm{OC})$ content $(n=3)$ and chl a $(n=3)$. Replicate subsample cores $(\varnothing=$ $10 \mathrm{~cm}$ ) were taken for determination of oxygen profiles ( $\mathrm{n}=3$, at stations for objective 2 only), and porewater nutrient profiles $\left(\mathrm{NH}_{4}-\mathrm{N}, \mathrm{NO}_{3}-\mathrm{N}, \mathrm{PO}_{4}-\mathrm{P}, \mathrm{D}-\mathrm{Si}\right)$ were obtained on replicate intact NIOZ cores $(n=3)$. Cores for particle size analysis (PSA), porosity, OC content, chl a and phaeophytin were sliced at $0.5 \mathrm{~cm}$ (top $1 \mathrm{~cm}$ ) and $1 \mathrm{~cm}$ (1 to $10 \mathrm{~cm}$ depth) intervals and stored at $-20^{\circ} \mathrm{C}$

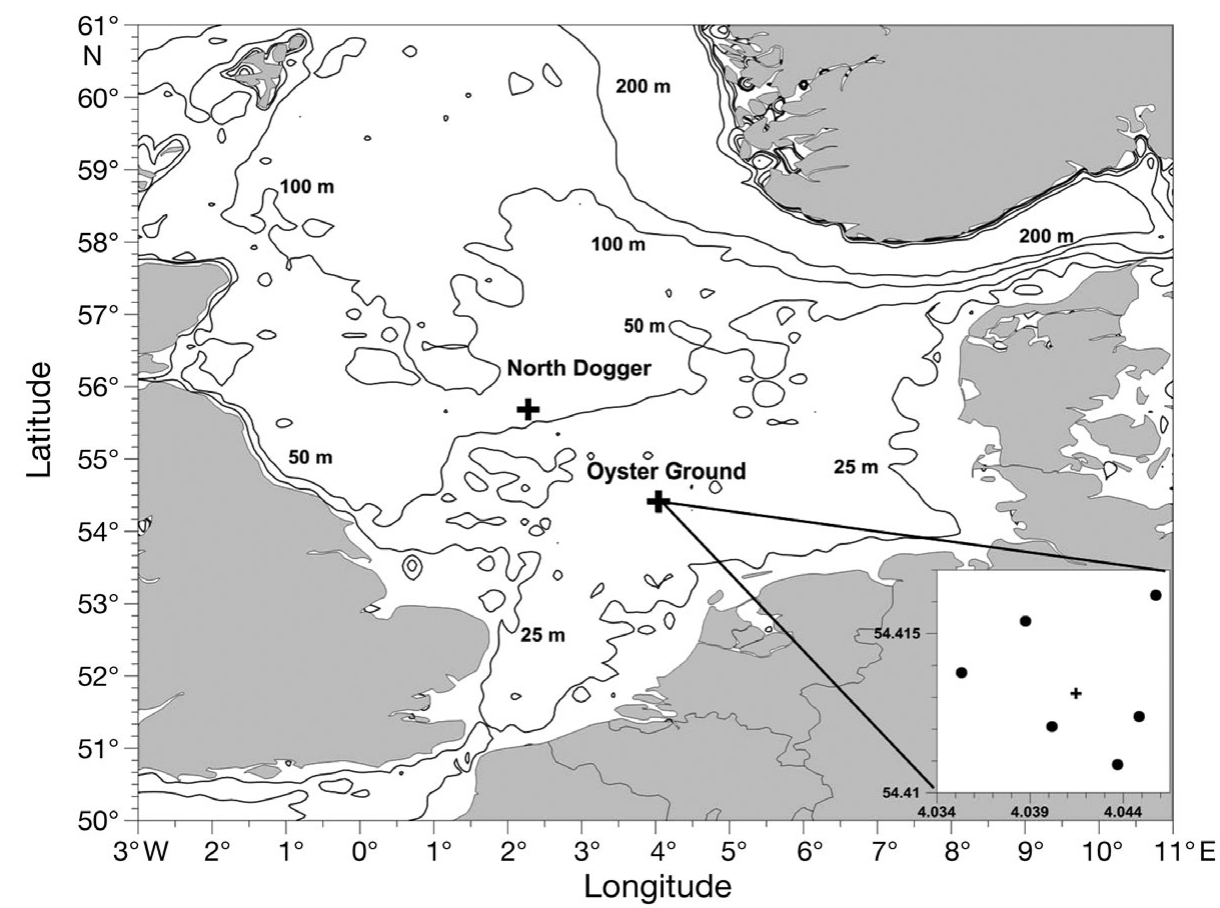

Fig. 1. Location of the Oyster Ground central station and North Dogger. Inset shows the locations of the 6 stations (closed circles) used for characterising the mixing depth, in addition to the central station at the Oyster Ground (cross). Lines indicate isobaths of given depths 
prior to analysis. Sediment pigment content and oxygen profiling (using polarographic oxygen microelectrodes, outer tip $\varnothing=100 \mu \mathrm{m}$ ) were processed immediately to avoid sample degradation. The porewater nutrient samples were filtered through a $0.2 \mu \mathrm{m}$ filter (Sartorius) prior to preservation with $\mathrm{HgCl}_{2}$ (Fisher Scientific) using the methodology described by Sivyer (1999).

During the February sampling campaign, at each of the 7 Oyster Ground stations, 2 constrained DET (diffusive equilibration in thin films; Davison et al. 2000, Fones et al. 2001) gel probes (DGT Research, total length $=15 \mathrm{~cm}$, divided into 75 compartments of $0.1 \times$ $0.1 \times 1.8 \mathrm{~cm}=0.018 \mathrm{~cm}^{3}$ ) were inserted into subsample cores $(\varnothing=10 \mathrm{~cm})$ to obtain high spatial resolution $(2 \mathrm{~mm})$ porewater Fe and $\mathrm{Mn}$ profiles. To avoid overestimation of $\mathrm{Fe}$ concentrations and minimise the effect of air exposure (Davison et al. 1994), all probes were held in a container of artificial seawater containing Chelex 100 and fully deoxygenated for $24 \mathrm{~h}$ using trace metal free, filtered nitrogen gas before immediately being inserted into each core.

To keep the ambient temperature constant and within $1.5^{\circ} \mathrm{C}$ of in situ temperatures, cores were maintained in aerated containers containing seawater obtained from $5 \mathrm{~m}$ off the seabed. The DET probes were left within each core to equilibrate for $11 \pm 1 \mathrm{~h}$. Concentrations (ppb) of the DET gel solutions, $C_{\text {ICP-MS }}$ were measured using Inductively Coupled PlasmaMass Spectrometry (ICP-MS) and used to calculate the metal concentrations $C_{\mathrm{g}}$ of each gel slice:

$$
C_{\mathrm{g}}=C_{\mathrm{ICP}-\mathrm{MS}}\left(\left(\frac{V}{V}\right) \times 10\right)
$$

where $V$ is the extractant volume $(\mathrm{ml}), v$ is the volume of gel $(\mathrm{ml})$ and 10 is the dilution factor. Porewater concentrations, $C_{\mathrm{PW}}(\mu \mathrm{M})$, are further calculated using:

$$
C_{\mathrm{PW}}=C_{\mathrm{g}} \times \mathrm{X}
$$

where $x$ is the atomic mass of the element in question (Davison et al. 1994, Davison et al. 2000, Fones et al. 2001).

Although the gel slices were available at $2 \mathrm{~mm}$ resolution, only every 5 th gel slice was analysed for each DET probe to obtain profiles at $1 \mathrm{~cm}$ resolution, which matched the maximum resolution available for other variables.

Determination of mixed depth. A sediment profile imaging (SPI) camera (for general principles, see Rhoads \& Cande 1971) was used to obtain in situ images $\left(15 \times 21.5 \mathrm{~cm}=322.50 \mathrm{~cm}^{2}\right)$ of the sediment profile. The imaging module is based around a Nikon D100 camera $(2000 \times 3000$ pixels $=6$ mega pixels, effective resolution $=75 \times 75 \mu \mathrm{m}$ per pixel), set to an exposure of $1 / 60$ and a film speed equivalent to ISO 400. Because colour is represented as a 3-dimensional number (red, green and blue [RGB] intensity), all images were converted to grey scale. During image analysis, each pixel within an RGB layer is converted into an 8-bit grey scale (i.e. 256 shades) and averaged with equal weighting to provide a pixel specific grey scale intensity value.

For images obtained in February 2007 at the Oyster Ground (objective 1), the mean grey scale intensity $(n=2000)$ across each depth (pixel) horizon was determined from replicate images $(n=3)$. The sedimentwater interface was manually traced on each image using the segmented line tool to define the upper limit of the region of interest. All pixel columns were then vertically realigned in relation to the segmented line to flatten the sediment-water interface. Grey scale intensity values of each pixel across each pixel horizon were summed and the mean grey scale intensity calculated for each pixel row. The grey scale profiles were then aggregated, using average grey scale values, to match the same resolution as the sediment chemistry profiles, i.e. $0.5 \mathrm{~cm}$ slices in the uppermost centimeter of the sediment and $1 \mathrm{~cm}$ slices from 1 to $10 \mathrm{~cm}$.

For the SPI time-series (objective 2) taken at the central station of the Oyster Ground (cross in inset of Fig. 1 ; $\mathrm{n}=3$ images $\times 5$ time points) and the North Dogger station ( $\mathrm{n}=3$ images $\times 5$ time points), the stepchange in image intensity (reflecting a visual transition from brown to olive green/black) was delineated using standard threshold analysis of 8-bit (greyscale) tagged image file format (TIFF) images. The upper limit of the region of interest was delineated by the sedimentwater interface, whilst the lower limit of the region of interest was determined by using the most appropriate threshold level that distinguished the oxidised sediment (higher reflectance) from the underlying reduced sediment (lower reflectance). The depth recognised by the step-change in grey scale intensity, hereinafter referred to as the mixing depth derived from image analysis $\left(\mathrm{MD}_{\mathrm{I}}\right)$, is defined as the mean vertical distance of the sediment area that has grey scale intensities above this user-defined threshold value. The $\mathrm{MD}_{\mathrm{I}}$ was determined from 10 images for each station and each time-point. Sediment underlying the $\mathrm{MD}_{\mathrm{I}}$ is hereinafter referred to as the underlying historic layer (UHL). All image analysis was performed using a custom-made, semi-automated macro (modified from Solan et al. 2004) within ImageJ (ver 1.38), a Javabased public domain program developed at the US National Institutes of Health (available at http:// rsb.info.nih.gov/ij/index.html).

Statistical analysis. Non-metric multidimensional scaling (nMDS, Shepard 1962) was used for a visual investigation of the differences in chemical composition and physical properties between the $\mathrm{MD}_{\mathrm{I}}$ and the UHL (objective 1) during February at the Oyster 
Ground. For each station (Oyster Ground site, 1 central station +6 peripheral stations, see Fig. 1), mean profiles were obtained for image grey scale $(\mathrm{n}=3)$, chl a $\left(\mathrm{mg} \mathrm{m}^{-2}, \mathrm{n}=3\right)$, carbon $\left(\mathrm{g} \mathrm{m}^{-3}, \mathrm{n}=3\right)$ and porewater Fe and $\mathrm{Mn}$ concentration profiles $(\mu \mathrm{M}, \mathrm{n}=2)$, as well as unreplicated $(\mathrm{n}=1)$ profiles for porosity, porewater nutrient profiles $\left(\mu \mathrm{M} \mathrm{I}^{-1}, \mathrm{NH}_{4}-\mathrm{N}, \mathrm{NO}_{3}-\mathrm{N}, \mathrm{PO}_{4}-\mathrm{P}, \mathrm{D}-\mathrm{Si}\right.$, $\mathrm{n}=1$ in all cases), and particulate adsorbed (ads) nutrients ( $\mu \mathrm{M} \mathrm{l}^{-1}, \mathrm{NH}_{4 \text {-ads, }} \mathrm{D}$-Si $\mathrm{ids}_{\mathrm{ads}} \mathrm{n}=1$ in both cases). All profiles were sliced/extracted at $1 \mathrm{~cm}$ resolution (from 0 to $10 \mathrm{~cm}$ depth), giving a total of 70 observations.

The dissimilarity matrix, on which nMDS is based, was calculated between all explanatory variables (i.e. chl $a$, total carbon, Fe, Mn, porosity, porewater nutrient profiles and particulate adsorbed nutrients) using Gower's symmetrical dissimilarity coefficient (Gower 1971). Gower's coefficient is used for quantitative data and is preferential for chemical and environmental data, as it treats zeros and non-zeros in the same way, as well as centering data on the basis of the range of each variable, thus being appropriate for dimensionally unequal data (i.e. different units, Legendre \& Legendre 1998). The nMDS was performed on the resulting matrix, and the appropriate dimensionality (i.e. the 'best' number of dimensions required to visualise groupings without over-modelling the data) was determined where the decrease in stress values (measure of goodness-of-fit of the regression of distance in the nMDS on dissimilarity) remained small with increasing dimensionality (Legendre \& Legendre 1998). An nMDS with a stress value of $<5 \%$ is considered to 'give excellent representation with no prospect of misinterpretation' (Clarke \& Warwick 2001, Chapter 5, p. 6). Grey scale intensity and sediment depth were not included in the dissimilarity matrix, as our primary focus was the clustering of data based on geochemical composition. However, to facilitate exploration of any potential relationship between geochemical composition and sediment depth and/or grey scale intensity, the resulting nMDS visualisation incorporates these variables. The significance of the dissimilarity between the groups of observations from within the $\mathrm{MD}_{\mathrm{I}}$ and those within UHL was assessed using analysis of similarities (ANOSIM) (Clarke \& Warwick 1993).

In order to determine which variables influence the depth of the $\mathrm{MD}_{\text {I }}$ (objective 2), the same statistical approach was used on the monthly data for chl a, faunal abundance and biomass, total carbon, porosity and oxygen penetration depth obtained from the central station of the Oyster Ground and the North Dogger station. In all cases a mean $(n=3)$ value per season and per site was used. As 10 SPI images had been taken at each station, the 3 with the deepest penetration (thus the most extensive grey scale profiles) were selected for analysis. To test for any significant differences in
$\mathrm{MD}_{\mathrm{I}}$ during pre- and post-spring and autumn phytoplankton bloom conditions at both stations, MannWhitney $U$-Tests (2-tailed) were applied to all images where a reliable $\mathrm{MD}_{\text {I }}$ was quantified (i.e. poor quality images were omitted where, for example, penetration was too shallow to see a step-change in image intensity within the available profile).

All analyses were performed using the 'vegan' (Oksanen et al. 2008) and 'MASS' (Venables \& Ripley 2002) packages in the ' $R$ ' statistical and programming environment (R Development Core Team 2008).

\section{RESULTS}

\section{Sediment grey scale}

Absolute values of the variables at each of the 7 stations at the Oyster Ground in February 2007 differed between stations (see Fig. S1, panels a-n, in the supplement at www.int-res.com/articles/suppl/m414p027_ supp.pdf), but an overall mean trend with depth was still detectable for each variable (Fig. 2). Mean trends showed either a decrease with depth (grey scale, chl a, carbon, porosity, total oxidised nitrogen (toxN), $\mathrm{NO}_{3}-\mathrm{N}$ ), an increase with depth (Fe, Mn, $\mathrm{NO}_{2}-\mathrm{N}, \mathrm{NH}_{4}-\mathrm{N}, \mathrm{D}-\mathrm{Si}$ ) or no well-defined pattern $\left(\mathrm{PO}_{4}-\mathrm{P}\right)$. $\mathrm{NH}_{4 \text {-ads }}$ and $\mathrm{D}$-Si $\mathrm{Sids}_{\text {ads }}$ also lacked a well-defined pattern but showed larger errors around the mean, which were due to higher values observed at Stns $5\left(\mathrm{NH}_{4 \text {-ads }}\right)$ and 4 (D-Si $\left.\mathrm{Ddds}_{\text {ads }}\right)$ relative to those of the remaining stations (see Fig. S1 panels 1 and m, respectively, in the supplement).

The nMDS reveals a separation between observations taken from within the $\mathrm{MD}_{\mathrm{I}}$ (left) and those taken from within the UHL (right; Fig. 3a). The 5 points separated from the main cluster with lower values along the second nMDS coordinate ( $x$-axis) were linked to higher chl $a$ and $\mathrm{NH}_{4 \text {-ads }}$ values measured at Stn 5 (see Fig. S1, panels e and 1 respectively). The separation of the 2 layers along the first nMDS coordinate is consistent with an increase in depth (Fig. 3b) and a decrease in grey scale intensity (Fig. 3c), where higher values denote higher reflectance (lighter) sediment and lower values denote underlying lower reflectance (darker) sediment. This pattern is maintained across stations such that the $\mathrm{MD}_{\mathrm{I}}$ can be separated from the UHL on the basis of the variables measured. The step-change in grey scale intensity is thus consistent with a stepchange in the geochemical composition of the 2 sediment layers. The visual difference evident between the $\mathrm{MD}_{\mathrm{I}}$ and the UHL (Fig. 3) is confirmed as statistically significant (ANOSIM: $\mathrm{R}=0.229, \mathrm{p}=0002$ ).

Although an $\mathrm{MD}_{\mathrm{I}}$-UHL boundary is clearly visible, defining the environmental variables that drive this separation is difficult because of the numerous inter- 

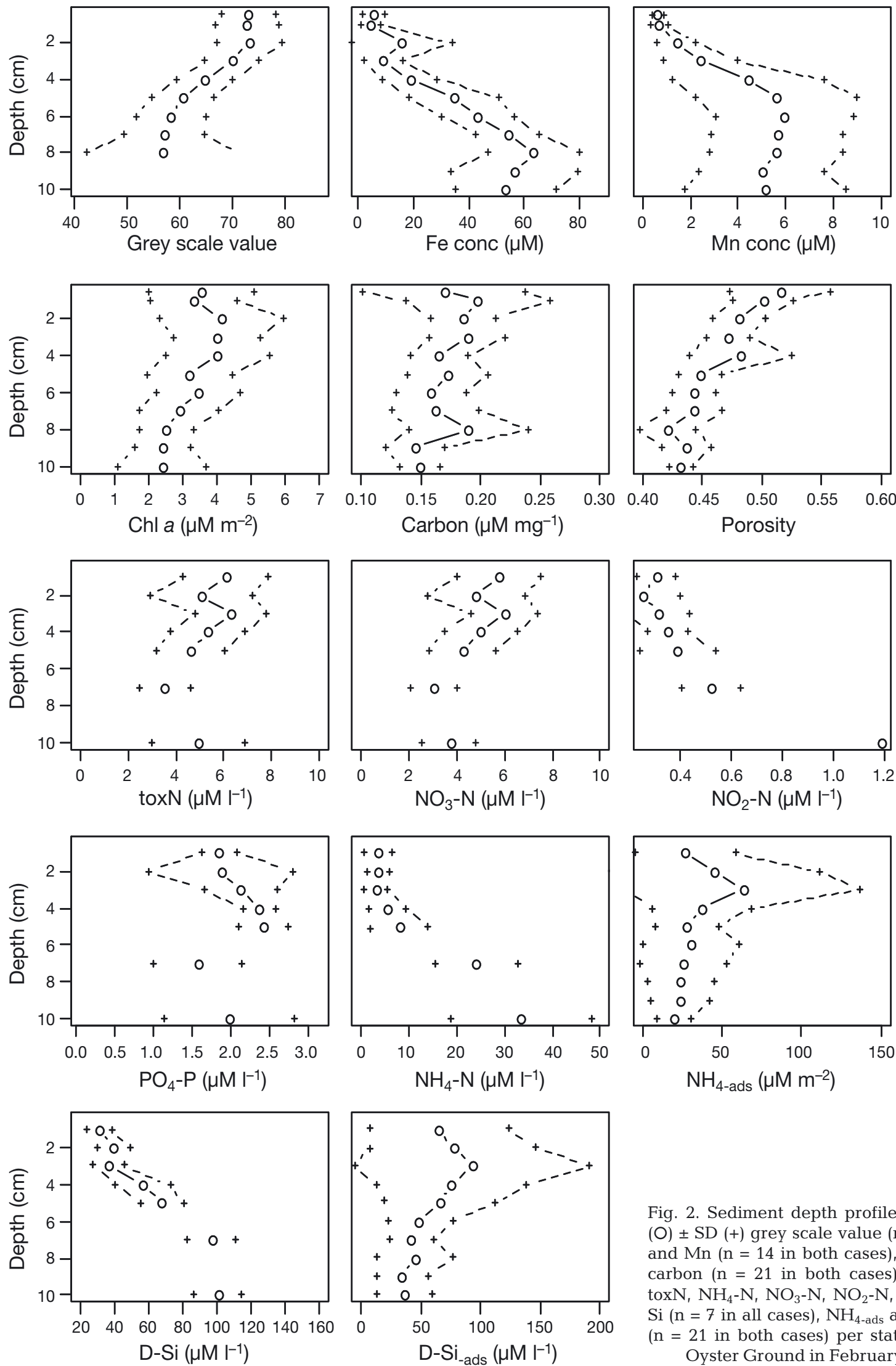

Fig. 2. Sediment depth profiles of mean (O) $\pm \mathrm{SD}(+)$ grey scale value $(\mathrm{n}=21), \mathrm{Fe}$ and $\mathrm{Mn}$ ( $\mathrm{n}=14$ in both cases), chl $a$ and carbon ( $\mathrm{n}=21$ in both cases), porosity, toxN, $\mathrm{NH}_{4}-\mathrm{N}, \mathrm{NO}_{3}-\mathrm{N}, \mathrm{NO}_{2}-\mathrm{N}, \mathrm{PO}_{4}-\mathrm{P}, \mathrm{D}-$ $\mathrm{Si}$ ( $\mathrm{n}=7$ in all cases), $\mathrm{NH}_{4 \text {-ads }}$ and $\mathrm{D}$-Si $\mathrm{ids}_{\text {ads }}$ ( $\mathrm{n}=21$ in both cases) per station at the Oyster Ground in February 2007 

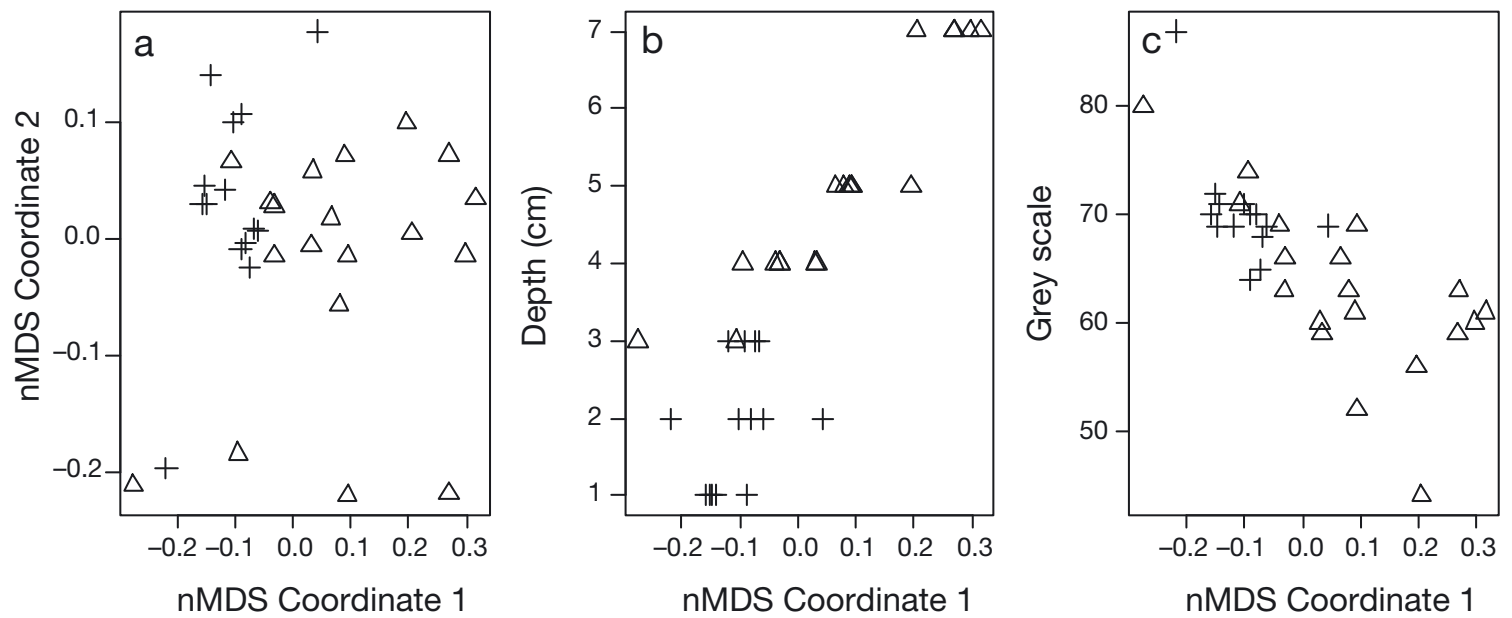

Fig. 3. nMDS ordination on chl a, total carbon, Fe, Mn, porosity, porewater nutrient profiles and particulate adsorbed nutrients showing (a) associated observations taken from within the mixing depth $(+)$ and those from the underlying historic sediment $(\Delta)$ for the Oyster Ground in February 2007. Distance between points (i.e. between $+\mathrm{s}$ and $\Delta \mathrm{s}$ ) corresponds to (dis)similarity between chemical and/or physical compositions of the observations. Scatterplots visualise the influence of (b) depth and (c) grey scale on the separation of observations along the first nMDS coordinate

actions between variables and with depth. It is evident that the separation of observations in the nMDS is due to a combination of variables rather than a single dominant variable (Fig. 4). The more prominent drivers behind the separation of observations along nMDS coordinate 1 are $\mathrm{Fe}, \mathrm{Mn}$ and $\mathrm{D}-\mathrm{Si}$, which show a positive relationship (Fig. 4) and therefore also a positive relationship with sediment depth and a negative relationship with grey scale intensity values. Although the relationship is less pronounced than for $\mathrm{Fe}, \mathrm{Mn}$ and $\mathrm{D}-\mathrm{Si}$, chl $\mathrm{a}$ and $\mathrm{NO}_{3}-\mathrm{N}$ show a negative relationship with nMDS coordinate 1 and therefore a positive relationship with grey scale values. The relatively higher values of chl a measured at Stn 5 are responsible for the separation of 5 of the observations to the right of the plot (Fig. 4). Whilst some relationships may be discernible in other variables, the variability increases considerably (Carbon, $\mathrm{NO}_{2}-\mathrm{N}, \mathrm{D}-\mathrm{Si}_{\mathrm{ads}}$ ), the site of step-change in concentrations does not occur at the $\mathrm{MD}_{\mathrm{I}}-\mathrm{UHL}$ boundary $\left(\mathrm{NH}_{4}-\mathrm{N}\right)$, and/or the separation of the 2 sediment layers is less pronounced with more overlap (porosity). Others $\left(\mathrm{PO}_{4}-\mathrm{P}\right)$ show no relationship at all (Fig. 4).

Thus, the step-change in image intensity (retrieved by grey scale level thresholding) observed in SPI images most likely separates low concentrations of Fe, $\mathrm{Mn}$ and D-Si and high chl a and $\mathrm{NO}_{3}-\mathrm{N}$ within the $\mathrm{MD}_{\mathrm{I}}$, from high concentrations of Fe, Mn and D-Si and low chl $a$ and $\mathrm{NO}_{3}-\mathrm{N}$ within the UHL.

\section{Depth of the $\mathrm{MD}_{\mathrm{I}}$}

The depth of the $\mathrm{MD}_{\mathrm{I}}$ differs considerably between sites (Fig. 1), as well as across sampling months
(Fig. 5). Although the $\mathrm{MD}_{\mathrm{I}}$ varies greatly at the Oyster Ground (coefficient of variation $=58 \%$ ), the mean $( \pm$ $\mathrm{SD}) \mathrm{MD}_{\mathrm{I}} \mathrm{s}$ gradually increase across the course of the year, ranging from $2.23 \pm 0.64 \mathrm{~cm}(\mathrm{n}=8)$ in February to $6.45 \pm 2.27 \mathrm{~cm}(\mathrm{n}=9)$ in October. At the North Dogger, however, the $\mathrm{MD}_{\mathrm{I}} \mathrm{s}$ are less variable (coefficient of variation $=28 \%$ ) and show no distinct increasing trend over the year. Monthly mean $\mathrm{MD}_{\mathrm{I}} \mathrm{S}( \pm \mathrm{SD})$ at the North Dogger range from $1.60 \pm 0.32 \mathrm{~cm}(\mathrm{n}=10)$ in April to $2.45 \pm 0.63 \mathrm{~cm}(\mathrm{n}=10)$ in May. $\mathrm{MD}_{\mathrm{I}} \mathrm{s}$ measured in prephytoplankton bloom conditions (April and September) are at least marginally shallower than $\mathrm{MD}_{\mathrm{I}} \mathrm{s}$ measured during post phytoplankton blooms (May and October) at both sites (Mann-Whitney U-tests, Fig. 5), suggesting that food availability might be an important contributory factor in directly or indirectly determining the depth of the $\mathrm{MD}_{\mathrm{I}}$.

Prevailing environmental conditions differ distinctly between the Oyster Ground and North Dogger (compare left and right cluster, Fig. 6). At the Oyster Ground, 3 clusters (April/May, September/October, and February; Fig. 6a) are clearly delineated, whilst at the North Dogger only 2 clusters (April/May, September/October/February; Fig. 6a) that broadly distinguish seasonal effects form. These groupings do not, however, correspond to either deeper or shallower $\mathrm{MD}_{\mathrm{I}} \mathrm{s}$ (Fig. 6b), suggesting that environmental and biological conditions vary between sites and seasons but are not necessarily expressed by the $\mathrm{MD}_{\mathrm{I}} \mathrm{s}$.

These inter-site differences in environmental conditions may be explained, at least in part, by relative differences in sediment surface carbon levels and faunal abundances (Fig. 7). Higher faunal biomass levels at the North Dogger in both April and Septem- 

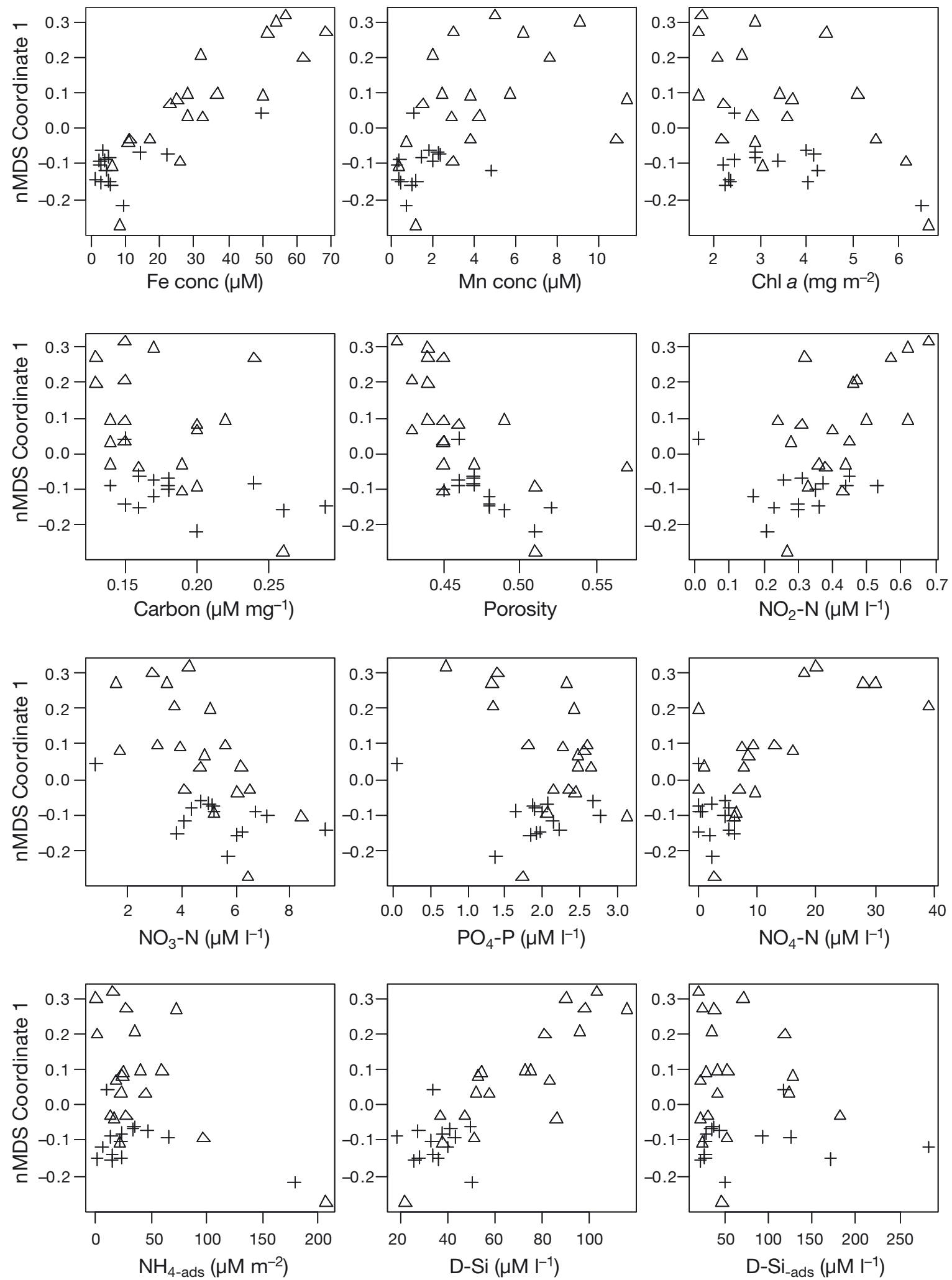

Fig. 4. nMDS ordination on $\mathrm{chl} a$, total carbon, $\mathrm{Fe}, \mathrm{Mn}$, porosity, porewater nutrient profiles and particulate adsorbed (ads) nutrients, showing the influence of each respective explanatory variable (individual panels) on the separation of observations along the first nMDS coordinate. Crosses denote observations from within the mixing depth, triangles those from the underlying historic sediment 


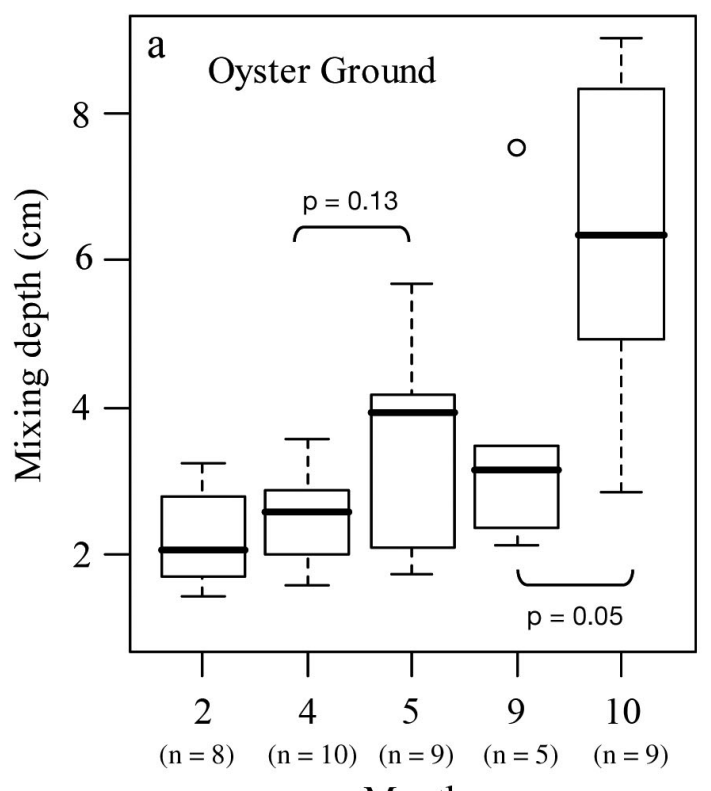

Month
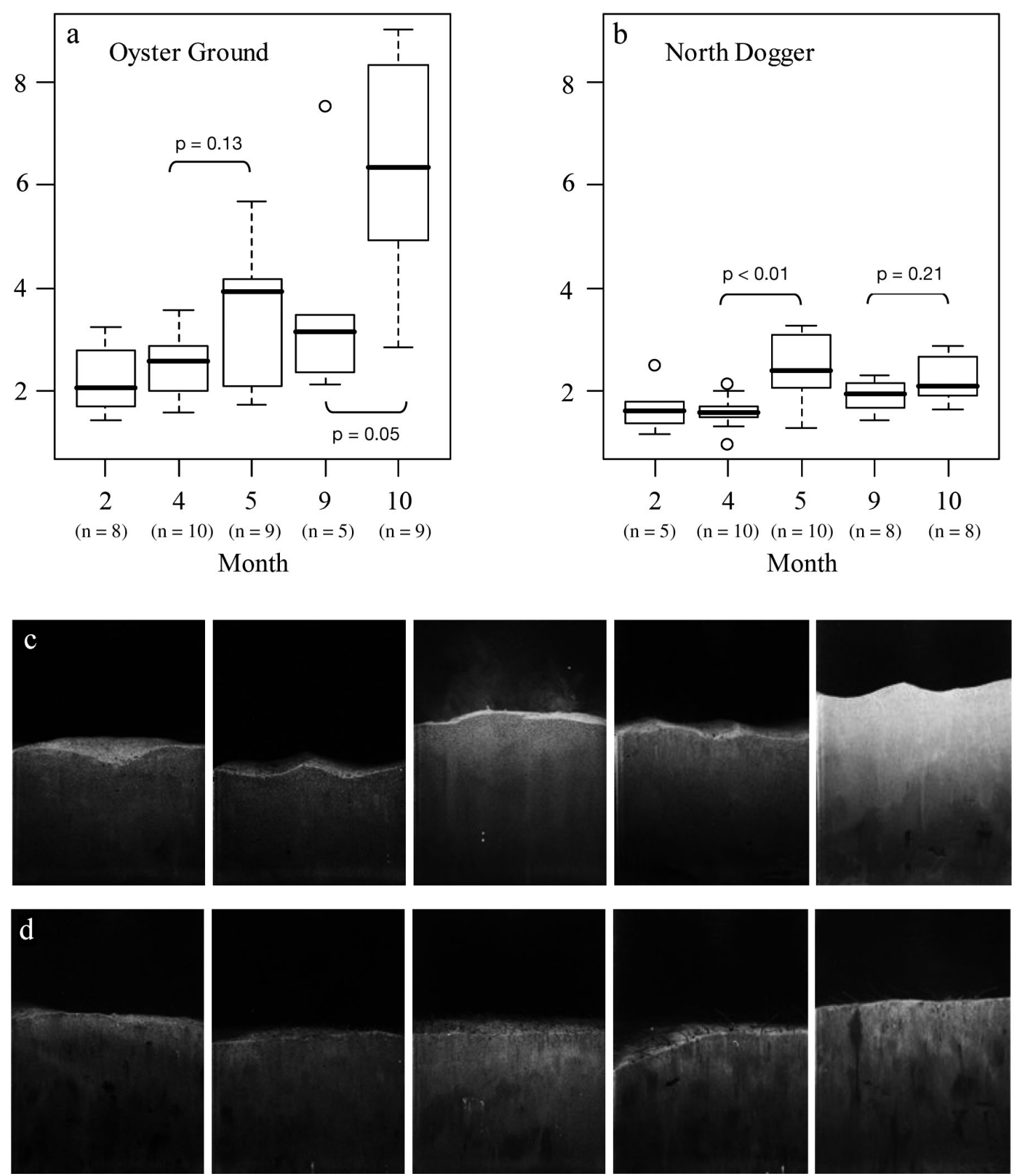

Fig. 5. Boxplot of the depth of $\mathrm{MD}_{\mathrm{I}} \mathrm{S}$ for 5 mo (2, February; 4, April; 5, May; 9, September; and 10, October) at (a) the Oyster Ground and (b) North Dogger. Thick horizontal lines show the median value, horizontal box lines show upper and lower quartiles, dashed vertical lines show the spread, and circles indicate outliers. p-values indicate probability associated with a 2-tailed Mann-Whitney $U$-test. Variability in number of images (n) is shown along the $x$-axis and is due to the removal of poor quality images (e.g. penetration too shallow) from the analysis. A representative sediment profile image (SPI) converted to grey scale is shown for the Oyster Ground (c) and North Dogger (d) for each of the 5 sampling mo (left to right)

ber reflect the presence of the large individuals of the bivalve Arctica islandica, although these observations do not appear to have affected any of the other variables. The separation between spring months and autumn/winter months is consistent with a change in chl a levels (Fig. 7).

\section{DISCUSSION}

The distinction of the $\mathrm{MD}_{\text {I }}$ from a UHL reflects 2 chemically distinct sediment layers that are associated with relative changes in the concentrations of dissolved $\mathrm{Fe}, \mathrm{Mn}, \mathrm{D}-\mathrm{Si}, \mathrm{chl} a$ and $\mathrm{NO}_{3}{ }^{-}$. Although these 2 

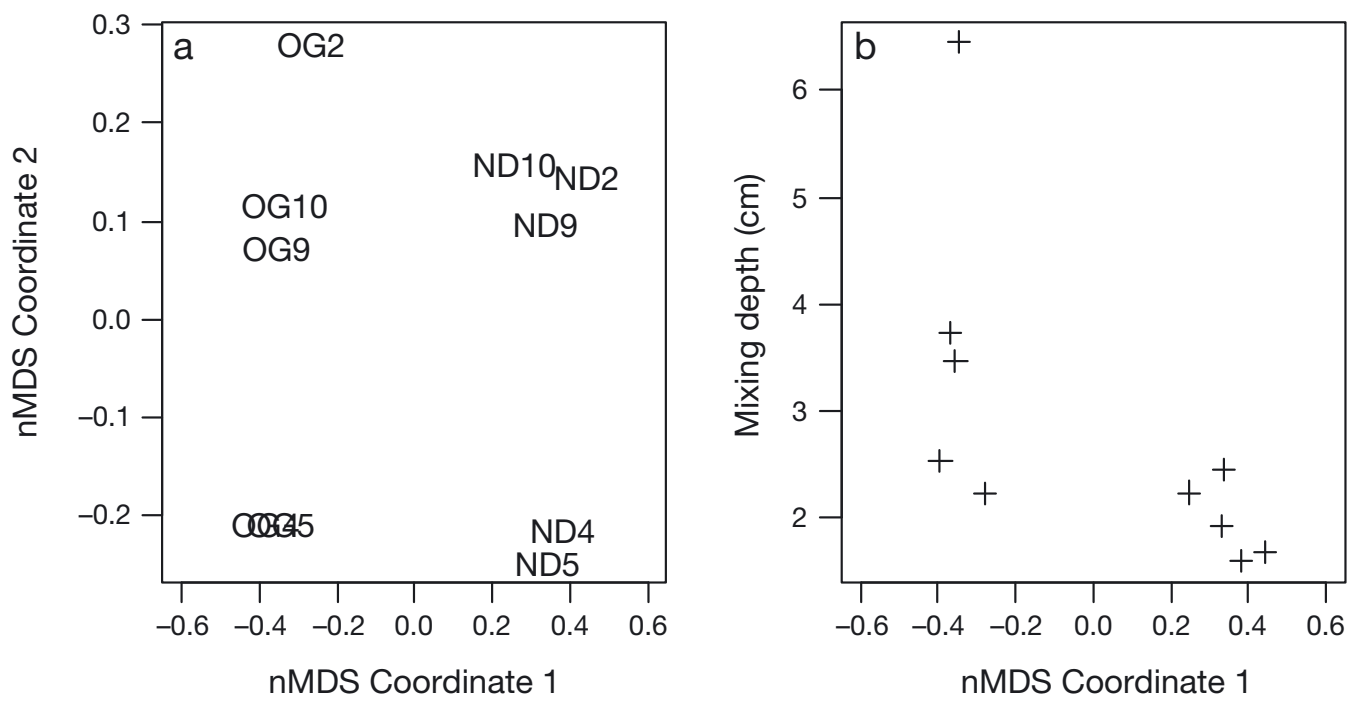

Fig. 6. nMDS ordination on surface chl a and carbon, oxygen penetration depth, porosity and faunal abundance and biomass showing associated (a) site (OG = Oyster Ground, ND = North Dogger) and season (month of observation). Distance between points corresponds to (dis)similarity between faunal parameters and environmental conditions between observations. Scatterplot

(b) of mixing depth $\left(\mathrm{MD}_{\mathrm{I}}\right)$ against nMDS coordinate 1 shows the relationship between the separation of points and the $\mathrm{MD}_{\mathrm{I}}$

layers of the sediment are shown to differ significantly in their chemical composition, the extent, or depth, of the higher reflective (light coloured) sediment on the surface cannot be directly related back to either faunal parameters or environmental influences alone. Instead, the depth of the $\mathrm{MD}_{\mathrm{I}}$ appears to reflect multiple processes that vary in time and space and is therefore highly context-dependent.

The changes observed in the chemical environment within the sediment profile are tightly coupled to well-known biogeochemical zonation patterns that reflect the sequential utilisation of electron acceptors for organic matter degradation (in order of decreasing energy yield, $\mathrm{O}_{2}, \mathrm{NO}_{3}{ }^{-}, \mathrm{Mn}$ and Fe oxides, $\mathrm{SO}_{4}{ }^{2-}$, and $\mathrm{CO}_{2}$; Aller 1982). Thus, although changes in concentrations of variables with depth are to be expected, a key finding is the importance of the relative concentrations of $\mathrm{Fe}, \mathrm{Mn}$ and $\mathrm{NO}_{3}-\mathrm{N}$ in separating the surface sediments $\left(\mathrm{MD}_{\mathrm{I}}\right)$ from the UHL. Unlike other reduction processes, the reduction of $\mathrm{Fe}$ and $\mathrm{Mn}$ oxides uses solid rather than dissolved electron acceptors. As Fe and Mn are released into the porewaters following reduction to a soluble form, their appearance in the UHL results from oxidation (Bull \& Williamson 2001, Teal et al. 2009), indicating, therefore, that the higher reflective regions of the sediment are sites where organic matter degradation (ecosystem function) is rapid and highly efficient (Schulz \& Zabel 2006, Teal et al. 2009, but see Kristensen et al. 1995). Further, the existence of lower concentrations of $\mathrm{NO}_{3}-\mathrm{N}$ alongside elevated concentrations of $\mathrm{NH}_{4}-\mathrm{N}$ within the $\mathrm{MD}_{\mathrm{I}}$, relative to the UHL, suggests that denitrification is taking place within the $\mathrm{MD}_{\mathrm{I}}$ and, therefore, adds credence to this view.

Vertical biogeochemical zonation can explain observed patterns in $\mathrm{Fe}, \mathrm{Mn}$ and $\mathrm{NO}_{3}-\mathrm{N}_{\text {; }}$ however, the relative change in chl a concentration across the $\mathrm{MD}_{\mathrm{I}^{-}}$ UHL boundary is derived from a separate process. Chl a integrates recent carbon input to the sediment surface, where it forms an important food source for benthic organisms (Josefson et al. 2002, Witte et al. 2003). The homogenous distribution of chl a throughout the $\mathrm{MD}_{\mathrm{I}}$, versus the more patchy distribution within the UHL, is an indication that the $\mathrm{MD}_{\mathrm{I}}$ corresponds to areas of maximal resource use and most intense infaunal mixing (Rhoads \& Germano 1986). Sediment OC, on the other hand, is indicative of long term carbon accumulation within the sediment (Burdige 2007). The discrepancy between carbon and chl $a$ indicates therefore that sediment colour, or the $\mathrm{MD}_{\mathrm{I}}$, is more closely tied to recent inputs of carbon (food for benthic organisms) and associated mixing rather than incorporating longer term processes.

It should be noted here that the reflectivity of sediment, or sediment colour, rarely forms a linear vertical cline but rather a mosaic of distinct patches that reflect levels of microbial activity, the provision of electron acceptors, and the availability of organic matter within the sediment profile (Aller 1984, Bertics \& Ziebis 2009). Utilising image analysis techniques, as in this study, provides an $\mathrm{MD}_{\mathrm{I}}$ based on the reflective area in an image divided by the width of the image. Consequently, any unevenness in the $\mathrm{MD}_{\mathrm{I}}$-UHL boundary or the occurrence patches of oxidised sediment situated 

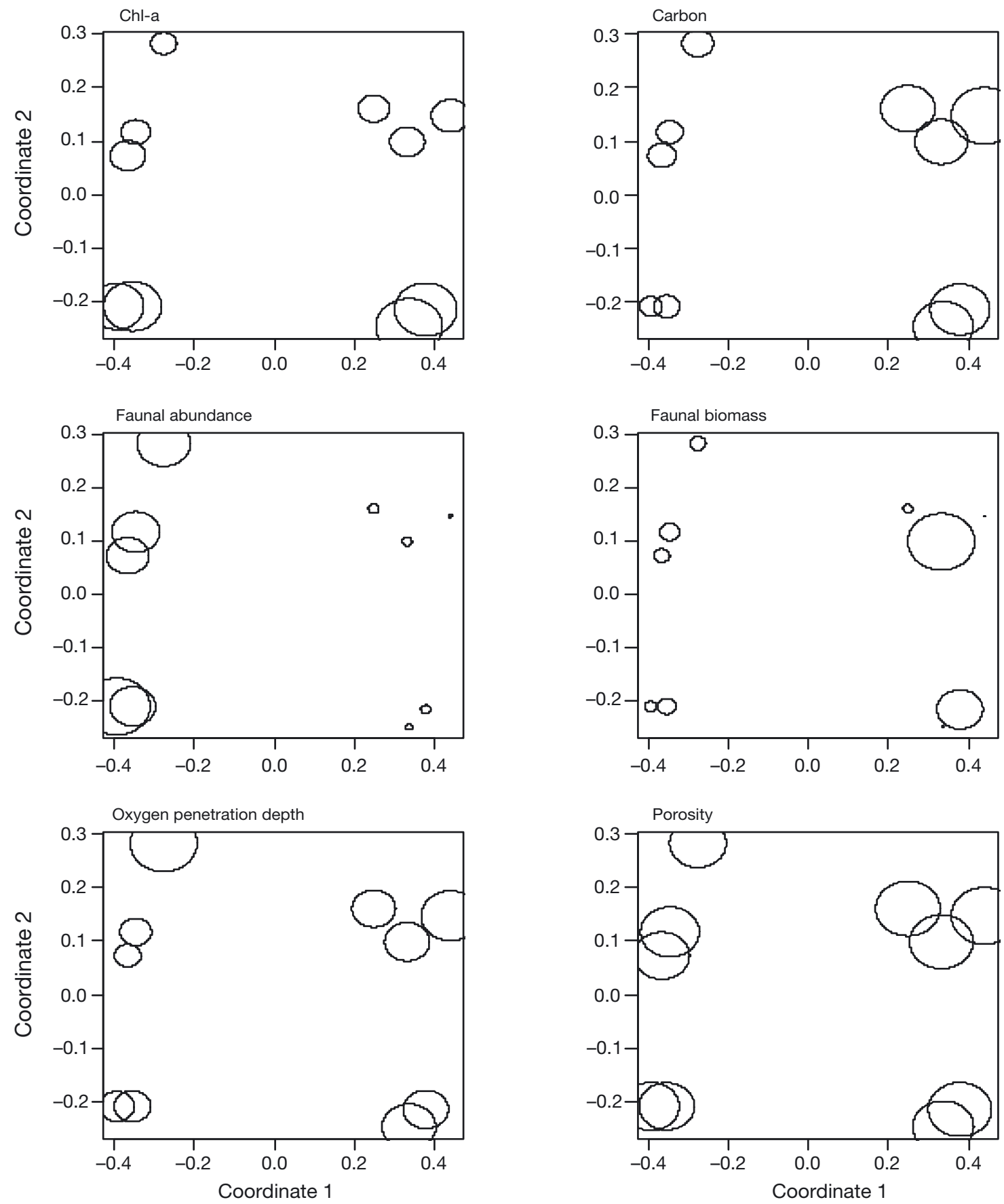

Fig. 7. nMDS ordination on surface chl $a$ and carbon, oxygen penetration depth, porosity and faunal abundance and biomass showing associated relative values of each of the 6 explanatory variables denoted above each panel. Circle diameters represent relative values of the respective variable. Centrepoints of the circles denote individual observations and can be compared to the same observations shown in Fig. 6a

below the boundary is incorporated, such that the $\mathrm{MD}_{\mathrm{I}}$ provides a true representation of reflective sediment throughout the image. Whilst this ensures a good estimate of the area capable of efficient organic matter degradation, profiles of sediment chemistry remain one-dimensional.
In terms of assessing benthic habitat quality, the results demonstrate that, for a representative temperate shelf sediment, reflective surface sediments represent regions of higher generic functional value. Although these conclusions validate the use of sediment profile image analysis as a means to separate sediment layers 
according to function, it is still necessary to understand which factors influence the depth of the $M D_{I}$ if the $M D_{I}$ is to be used as a proxy for habitat quality. It is evident here that numerous variables drive the depth of the $\mathrm{MD}_{\mathrm{I}}$ and that inferring causation between the extent of the $\mathrm{MD}_{\mathrm{I}}$ and such variables is complex. The seasonal comparisons across the 2 sites show that neither faunal abundance nor biomass are necessarily major determinants of the depth of $\mathrm{MD}_{\mathrm{I}}$. Whilst it is intuitive that these 2 factors should influence both faunal mixing intensities as well as depths of mixing, they will also vary depending on population biomass (e.g. Duport et al. 2006), vertical community distribution (e.g. Gérino et al. 1999), community composition (e.g. Duport et al. 2007), environmental factors (e.g. Orvain \& Sauriau 2002, Reiss \& Kröncke 2005), resource availability (e.g. Nogaro et al. 2008), functional richness (e.g. Mermollid-Blondin et al. 2004) and/or species diversity (e.g. Ieno et al. 2006). Importantly, however, interactions between environmental conditions and species composition mediate faunal influence on the $\mathrm{MD}_{\mathrm{I}}$ to such an extent that specific driving variables or the relative contributions of these different parameters to the $\mathrm{MD}_{\mathrm{I}}$ (e.g. Godbold \& Solan 2009) are unable to be identified in this study.

Interestingly, this can also explain some of the discrepancy observed between image (colour or grey scale) derived mixing depths $\left(\mathrm{MD}_{\mathrm{I}}\right)$ and tracer derived mixing depths found elsewhere (for review, see Teal et al. 2008), as particulate tracers emphasise particle movement alone and are therefore directly linked to faunal activity and behaviour. Colour (or grey scale) profiles, on the other hand, integrate a range of processes, including carbon input ( $\mathrm{chl} a$ ), nutrient $\left(\mathrm{NO}_{3}-\mathrm{N}\right)$ and trace metal cycling ( $\mathrm{Fe}$ and $\mathrm{Mn})$, which are further influenced by the environment, as well as biotic processes such as infaunal bioturbation (Thamdrup et al. 1994). The extent of the $\mathrm{MD}_{\mathrm{I}}$ is thus context-dependent (e.g. seasonal, Green et al. 2004) and site-specific and can be influenced by physical mixing (e.g. Yingst \& Aller 1982, Dellapenna et al. 1998), making it fundamentally different from tracer derived mixing depths. Attempts to relate the $\mathrm{MD}_{\text {I }}$ directly to benthic community measures alone are therefore unlikely to be satisfactory, even when patterns are highly correlated. Benthic indices making use of image derived mixing depths (previously called aRPD or BMD, e.g. Benthic habitat quality index, Nilsson \& Rosenberg 1997; Organism-sediment index, Valente et al. 1992) are widely used, but index values are usually reported without consideration of the full context under which the measurements were taken (Diaz et al. 2003) and are interpreted using phenomenological paradigms of ecological succession.
If we are to use the $\mathrm{MD}_{\mathrm{I}}$ as a proxy for benthic function in benthic habitat quality assessments, then the context-dependent processes which shape the biological and physical properties of the sediment must be taken into account and the relative roles of the principal influential variables established. It remains an open empirical question as to how each component contributes to different levels of ecosystem functioning, whether they interact in an additive manner or otherwise (Folt et al. 1999) and how the determinants of the $\mathrm{MD}_{\mathrm{I}}$ may change in light of current environmental change, biodiversity loss, as well as habitat loss and/or fragmentation. As these processes contribute to the perceived 'health' of marine benthic systems, caution needs to be exercised when making assessments and recommendations about how the quality of the seabed should be managed in support of living resources over longer time scales.

Acknowledgements. We gratefully acknowledge all crew and scientists of the RV 'Endeavour' (CEFAS) for their assistance and collaboration during the 2007 MEC cruise series. We thank K. Warr, L. Bristow, and E. Neubacher (CEFAS, Lowestoft) for their assistance in collating data included in this paper, and $\mathrm{H}$. Bates (CEFAS Burnham) for assistance in faunal identification. We are further grateful to G. Fones and S. Tierney (for DET and ICP-MS) from the University of Portsmouth, and A. Holford (for image analysis macros) and A. Douglas (for statistical advice) from the University of Aberdeen and B. Quiroz (for providing the map) from Station Marine de Wimereux. This work was supported by a University of Aberdeen 6th century studentship (awarded to L.R.T.) and CEFAS, Lowestoft (DP204). Funding of ship time was obtained through Defra MEC (E3205).

\section{LITERATURE CITED}

Aller RC (1982) The effects of macrobenthos on chemical properties of marine sediments and overlying water. In: Call PL, Tevesz MJS (eds) Animal-sediment relations, the biogenic alteration of sediments. Plenum Press, New York, NY, p 53-102

$>$ Aller RC (1984) The importance of relict burrow structures and burrow irrigation in controlling sedimentary solute distributions. Geochim Cosmochim Acta 48:1929-1934

Bertics VJ, Ziebis W (2009) Biodiversity of benthic microbial communities in bioturbated coastal sediments is controlled by geochemical microniches. ISME J 3:1269-1285

Bottjer DJ, Hagadorn JW, Dornbos SQ (2000) The Cambrian substrate revolution. GSA Today 10:1-7

Boudreau BP (1998) Mean mixed depth of sediments: the wherefore and the why. Limnol Oceanogr 43:524-526

Bull DC, Williamson RB (2001) Prediction of principal metalbinding solid phases in estuarine sediments from color image analysis. Environ Sci Technol 35:1658-1662

> Burdige DJ (2007) Preservation of organic matter in marine sediments: controls, mechanisms, and an imbalance in sediment organic carbon budgets? Chem Rev 107: $467-485$

Carpenter R, Peterson MZ, Bennett JT (1985) ${ }^{210} \mathrm{~Pb}$-derived sediment accumulation and mixing rates for the greater Puget Sound region. Mar Geol 64:291-312 
Clarke KR, Warwick RM (1994) Similarity-based testing for community pattern: the two-way layout with no replication. Mar Biol 118:167-176

Clarke KR, Warwick RM (2001) Change in marine communities: an approach to statistical analysis and interpretation, 2nd edn (revised). PRIMER-E, Plymouth, UK

$>$ Davison W, Zhang H, Grime GW (1994) Performance characteristics of gel probes used for measuring the chemistry of pore waters. Environ Sci Technol 28:1623-1632

Davison W, Fones GR, Harper M, Teasdale P, Zhang H (2000) Dialysis, DET and DGT: in situ diffusional techniques for studying water, sediments and soils. In: Buffle J, Horvai G (eds) In situ monitoring of aquatic systems: chemical analysis and speciation. IUPAC. Wiley, New York, NY, p 496-569

> Dellapenna TM, Kuehl SA, Schaffner LC (1998) Sea-bed mixing and particle residence times in biologically and physically dominated estuarine systems: a comparison of lower Chesapeake Bay and the York River Subestuary. Estuar Coast Shelf Sci 46:777-795

> Diaz RJ (2004) Biological and physical processes structuring deep-sea surface sediments in the Scotia and Weddell Seas, Antarctica. Deep-Sea Res II 51:1515-1532

> Diaz RJ, Trefry JH (2006) Comparison of sediment profile image data with profiles of oxygen and Eh from sediment cores. J Mar Syst 62:164-172

> Diaz RJ, Cutter GR, Dauer DM (2003) A comparison of two methods for estimating the status of benthic habitat quality in the Virginia Chesapeake Bay. J Exp Mar Biol Ecol 285-286:371-381

Diaz RJ, Solan M, Valente RM (2004) A review of approaches for classifying benthic habitats and evaluating habitat quality. J Environ Manag 73:165-181

Duport E, Stora G, Tramblay P, Gilbert F (2006) Effects of population density on the sediment mixing induced by the gallery-diffusor Hediste (Nereis) diversicolor O.F. Müller, 1776. J Exp Mar Biol Ecol 336:33-41

Duport E, Gilbert F, Poggiale J-C, Dedieu K, Rabouille C, Stora G (2007) Benthic macrofauna and sediment reworking quantification in contrasted environments in the Thau Lagoon. Estuar Coast Shelf Sci 72:522-533

Fenchel T (1969) The ecology of marine microbenthos IV. Structure and function of the benthic ecosystem, its chemical and physical factors and the microfauna communities with special reference to the ciliated protozoa. Ophelia 6:1-182

Folt CL, Chen CY, Moore MV, Burnaford J (1999) Synergism and antagonism among multiple stressors. Limnol Oceanogr 44:864-877

Fones GR, Davison W, Holby O, Jorgensen BB, Thamdrup B (2001) High-resolution metal gradients measured by in situ DGT/DET deployment in Black Sea sediments using an autonomous benthic lander. Limnol Oceanogr 46: 982-988

Gehling JG (1999) Microbial mats in terminal Proterozoic siliciclastics: Ediacaran death masks. Palaios 14:40-57

Gérino M, Stora G, Weber O (1999) Evidence of bioturbation in the Cap-Ferret Canyon in the deep northeastern Atlantic. Deep-Sea Res II 46:2289-2307

Godbold JA, Solan M (2009) Relative importance of biodiversity and the abiotic environment in mediating an ecosystem process. Mar Ecol Prog Ser 396:273-282

> Gower JC (1971) A general coefficient of similarity and some of its properties. Biometrics 27:857-871

Green MA, Gulnik JD, Dowse N, Chapman P (2004) Spatiotemporal patterns of carbon remineralisation and bioirrigation in sediments of Casco Bay Estuary, Gulf of Maine. Limnol Oceanogr 49(2):396-407
Guinasso NL, Shink DR (1975) Quantitative estimates of biological mixing rates in abyssal sediments. J Geophys Res 80:3032-3043

Ieno EN, Solan M, Batty P, Pierce GJ (2006) How biodiversity affects ecosystem functioning: roles of infaunal species richness, identity and density in the marine benthos. Mar Ecol Prog Ser 311:263-271

Johnson RG (1972) Conceptual models of benthic marine communities. In: Schopf TJM (ed) Models in paleobiology. Freeman, San Francisco, CA, p 148-156

Josefson AB, Forbes TL, Rosenberg R (2002) Fate of phytodetritus in marine sediments: functional importance of macrofaunal community. Mar Ecol Prog Ser 230:71-85

> Kristensen E, Ahmed AI, Devol AH (1995) Aerobic and anaerobic decomposition of organic matter in marine sediment: Which is fastest? Limnol Oceanogr 40:1430-1437

Lecroart P, Schmidt S, Anschutz P, Jouanneau JM (2007) Modeling sensitivity of biodiffusion coefficient to seasonal bioturbation. J Mar Res 65:417-440

Legendre P, Legendre L (1998) Numerical ecology. Elsevier Scientific Publishing, Amsterdam

Lyle M (1983) The brown-green color transition in marine sediments: a marker of the Fe(III)-Fe(II) redox boundary. Limnol Oceanogr 28:1026-1033

Martin RE, Quigg A, Pdkovyrov V (2008) Marine biodiversification in response to evolving phytoplankton stoichiometry. Palaeogeogr Palaeoclimatol Palaeoecol 258:277-291

McIlroy D, Logan GA (1999) The impact of bioturbation on infaunal ecology and evolution during the ProterozoicCambrian transition. Palaios 14:58-72

Mermillod-Blondin F, Rosenberg R, François-Carcaillet F, Norling K, Mauclaire L (2004) Influence of bioturbation by three benthic infaunal species on microbial communities and biogeochemical processes in marine sediment. Aquat Microb Ecol 36:271-284

> Nilsson HC, Rosenberg R (1997) Benthic habitat quality assessment of an oxygen stressed fjord by surface and sediment profile images. J Mar Syst 11:249-264

> Nogaro G, Charles F, Brage de Mendonça J Jr, MermillodBlondin F, Stora G, François-Carcaillet F (2008) Food supply impacts sediment reworking by Nereis diversicolor. Hydrobiologia 598:403-408

Oksanen J, Kindt R, Legendre P, O'Hara B and others (2008) vegan: Community Ecology Package. Available: www. stats.bris.ac.uk/R/.

> Orvain F, Sauriau PG (2002) Environmental and behavioural factors affecting activity in the intertidal gastropod Hydrobia ulvae. J Exp Mar Biol Ecol 272:191-216

Pearson TH, Rosenberg R (1978) Macrobenthic succession in relation to organic enrichment and pollution of the marine environment. Oceanogr Mar Biol Annu Rev 16:229-311

R Development Core Team (2008) R: a language and environment for statistical computing. Vienna R Foundation for Statistical Computing. Available: www.r-project.org

> Reiss H, Kröncke I (2005) Seasonal variability of infaunal community structures in three areas of the North Sea under different environmental conditions. Estuar Coast Shelf Sci 65:253-274

Revsbech NP, Jørgensen BB, Blackburn TH (1979) Oxygen in the sea bottom measured with a microelectrode. Science 207:1355-1356

> Rhoads DC, Cande S (1971) Sediment profile camera for in situ study of organism-sediment relations. Limnol Oceanogr 16:110-114

Rhoads DC, Germano JD (1986) Interpreting long-term changes in benthic community structure: a new protocol. Hydrobiologia 142:291-308 
Rosenberg R, Nilsson HC, Diaz RJ (2001) Response of benthic fauna and changing sediment redox profiles over a hypoxic gradient. Estuar Coast Shelf Sci 53:343-350

Rosenberg R, Blomqvist M, Nilsson HC, Cederwall H, Dimming A (2004) Marine quality assessment by use of benthic species-abundance distributions: a proposed new protocol within the European Union Water Framework Directive. Mar Pollut Bull 49:728-739

Schulz H, Zabel M (2006) Marine biogeochemistry. Springer, Berlin

Seilacher A, Pflüger F (1994) From biomats to benthic agriculture: a biohistoric revolution. In: Krumbein WE, Paterson DM, Stal LJ (eds) Biostabilisation of sediments. Bibliotheks und Informationssystem der Carl von Ossietzky Universität Oldenburg (BIS)

Shepard RN (1962) The analysis of proximities: multidimensional scaling with an unknown distance function. I. Psychometrika 27:125-140

Sivyer DB (1999) Nitrogen cycling in intertidal sediments of the Wash, UK. MSc by Research Thesis, University of East Anglia

Smith CR, Rabouille C (2002) What controls the mixed-layer depth in deep-sea sediments? The importance of POC flux. Limnol Oceanogr 47:418-426

Smith CR, Pope RH, DeMaster DJ, Magaard L (1993) Agedependant mixing of deep-sea sediments. Geochim Cosmochim Acta 57:1473-1488

Snelgrove PVR, Butman CA (1994) Animal sediment relationships revisited-cause versus effect. Oceanogr Mar Biol Annu Rev 32:111-177

Solan M, Cardinale BJ, Downing AL, Engelhardt KAM, Ruesink JL, Srivastava DS (2004) Extinction and ecosystem function in the marine benthos. Science 306:

Editorial responsibility: Ronald Kiene,

Mobile, Alabama, USA
$1177-1180$

Suchanek TH (1983) Control of seagrass communities and sediment distribution by Callianassa (Crustacea, Thalassinidea) bioturbation. J Mar Res 41:281-298

Teal LR, Bulling MT, Parker ER, Solan M (2008) Global patterns of bioturbation intensity and mixed depth of marine soft sediments. Aquat Biol 2:207-218

Teal LR, Parker ER, Fones G, Solan M (2009) Simultaneous determination of vertical transitions of colour, porewater metals and visualization of infaunal activity in marine sediments. Limnol Oceanogr 54:1801-1810

Thamdrup B, Fossik H, Jørgensen BB (1994) Manganese, iron, and sulfur cycling in a coastal marine sediment, Aarhus Bay, Denmark. Geochim Cosmochim Acta 58: 5115-5129

Valente RM, Rhoads DC, Germano JD, Cabelli VJ (1992) Mapping of benthic enrichment patterns in Narragansett Bay, Rhode Island. Estuaries 15:1-17

Venables WN, Ripley BD (2002) Modern applied statistics with $\mathrm{S}$, 4th edn (revised). Springer, New York, NY

Wheatcroft RA (1992) Experimental tests for particle sizedependant bioturbation in the deep ocean. Limnol Oceanogr 37:90-104

Witte U, Wenzhofer F, Sommer S, Boetius A and others (2003) In situ experimental evidence of the fate of a phytodetritus pulse at the abyssal sea floor. Nature 424:763-766

Yingst JY, Aller RC (1982) Biological activity and associated sedimentary structures in Hebble-area deposits, western North Atlantic. Mar Geol 48:M7-M15

Zajac RN (2001) Organism-sediment relations at multiple spatial scales: implications for community structure and successional dynamics. In: Aller JY, Woodin SA, Aller RC (eds) Organism-sediment interactions. University of South Carolina Press, Columbia, SC, p 119-139

Submitted: January 27, 2010; Accepted: July 15, 2010

Proofs received from author(s): August 30, 2010 